\title{
The Reverse Gender Gap in Volunteer Activities: Does Culture Matter?
}

\author{
Héctor Bellido (D), Miriam Marcén * (D) and Marina Morales \\ Departamento de Análisis Económico, Facultad de Economía y Empresa, Universidad de Zaragoza, \\ 50005 Zaragoza, Spain; hbellido@unizar.es (H.B.); mcmorales@unizar.es (M.M.) \\ * Correspondence: mmarcen@unizar.es
}

Citation: Bellido, H.; Marcén, M.; Morales, M. The Reverse Gender Gap in Volunteer Activities: Does Culture Matter? Sustainability 2021, 13, 6957. https://doi.org/10.3390/su13126957

Academic Editor:

Jennifer Martínez-Ferrero

Received: 19 May 2021

Accepted: 17 June 2021

Published: 21 June 2021

Publisher's Note: MDPI stays neutral with regard to jurisdictional claims in published maps and institutional affiliations.

Copyright: (c) 2021 by the authors. Licensee MDPI, Basel, Switzerland. This article is an open access article distributed under the terms and conditions of the Creative Commons Attribution (CC BY) license (https:// creativecommons.org/licenses/by/ $4.0 /)$.

\begin{abstract}
Women take on 57\% (men: 43\%) of all volunteering globally (UN 2018). In this paper, we follow an epidemiological approach to explore the possible role of culture in determining this reverse gender gap in the time devoted to volunteer activities. To that end, we merge data from the American Time Use Survey for the years 2006-2019 and the Gender Gap Index (GGI) of the World Economic Forum 2021. We use a sample of early-arrival first- and second-generation immigrants who live in the United States. Our empirical approach rests on the fact that all these individuals have grown up under the same host country's labor market, regulations, laws, and institutions but differ in their cultural heritage. Thus, in this setting, gender discrepancies in the time devoted to volunteer activities can be interpreted as the effect of culture. We find that more gender-equal norms in the country of origin are associated with women devoting less time to volunteer activities relative to men. We further analyze the channels shaping the culture from the country of ancestry and the existence of horizontal (within-communities) transmission of culture. Our results are robust to the use of different subsamples and to the inclusion of demographic and socio-economic controls.
\end{abstract}

Keywords: volunteer activities; culture; immigrants; American time use survey

\section{Introduction}

Volunteering is the practice of providing charitable goods and services for the benefit of another person, group, or organization [1]. Volunteering's impact across the world is non-negligible as it is considered as a global vehicle for sustainable development (2030 UN Agenda for Sustainable Development). Volunteering globally has reached 109 million full-time equivalent workers (UN 2018). This is comparable with the labor force of Brazil, roughly 100 million or the fifth largest in the world (World Bank 2020). Across countries, data on volunteering reveal regional variations in volunteer participation rates from roughly 29 million in Asia and the Pacific, Europe and Central Asia to 9 million in Arab states, Latin America and the Caribbean. However, there are also social differences within countries. Overall, volunteering is undertaken by a greater proportion of women than men (57 vs. $43 \%$ ), and this is maintained across all regions except Asia and the Pacific (UN 2018). Understanding the factors driving volunteering is an important issue. The motivations for volunteer behavior have been studied extensively, focusing on behavioral factors such as altruism, social reputation, and/or monetary incentives [2], but traditional roles (culture) can also play a part. Although there is some recent cross-country evidence on the possible relationship between gender equality and the volunteering habits of men and women $[3,4]$, causality cannot be derived from these studies because of the difficulties in separating the effect of culture from that of markets, laws, and institutions. To fill this gap in the literature, we exploit the differences in the cultural heritage of early-arrival firstand second-generation immigrants living in the same country (with the same markets, laws, and institutions), the US, to evaluate the effect of culture on the reverse gender gap in the time devoted to volunteer activities. 
Regarding the definition of culture, we follow the United Nations Educational, Scientific and Cultural Organization (UNESCO 2001), which defines culture as "the set of distinctive spiritual, material, intellectual, and emotional features of society or a social group. Not only does this encompass art and literature, but it also includes lifestyles, ways of living together, value systems, traditions, and beliefs". This concept of culture has recently attracted the attention of researchers, who have studied its implications for many socioeconomic and demographic outcomes $[5,6]$. Using methodologies that are quite analogous to ours, prior research has provided empirical evidence on the importance of culture to living arrangements [7,8], employment and fertility [9-16], divorce [17], homeownership [18], the gender division of household labor [19,20], and even the math, reading, and science gender gap [21,22], among others.

We contribute to these substantial pieces of literature by investigating whether culture explains gender differences in the time devoted to volunteer activities. Although prior research has suggested that culture is an important determinant of human behavior [6], distinguishing the role of culture/social norms from that of institutions and economic conditions is a challenge due to their close interrelationship [16,17]. To disentangle the two effects and isolate that of culture itself, we follow an epidemiological approach [16]. We focus on early-arrival first- and second-generation immigrants who have grown up under the same host country's labor market, regulations, laws, and institutions but are also influenced by a different cultural heritage. With this purpose, we merge data from the American Time Use Survey for the years 2006-2019 [23] and the World Economic Forum's Gender Gap Index (GGI) for the same period, which reflects economic and political opportunities, education, and well-being for women in the country of ancestry. We estimate the effect of the GGI (proxy of culture) measured by country of ancestry on the time devoted to volunteer activities of early-arrival first- and second-generation immigrant women over men. We find that more gender-equal norms in the country of origin are associated with a smaller reverse gender gap in the time devoted to volunteer activities. This result is robust to the use of different samples, the incorporation of more controls, and the use of alternative methodologies.

Our analysis rests on the assumption that there is a transmission of culture to our sample of early-arrival first- and second-generation immigrants. If we are really identifying a cultural effect, we should observe evidence pointing to that possible transmission. On the one hand, vertical transmission (from parents or other ancestors) may play a part here, but with our dataset this cannot be examined [17]. On the other hand, culture may be horizontally transmitted through neighbors or ethnic communities where individuals live. The higher the concentration of individuals of the same ethnicity, the greater the horizontal transmission of culture [21]. Our results provide empirical evidence in favor of this horizontal transmission reinforcing the validity of our empirical design. This is a key element supporting the identification of the cultural impact.

If culture really matters, we should find evidence of the channels through which culture operates. We extend our analysis by exploring the mechanism through which culture operates. We use each of the four components of the GGI to explore which of the gender equality aspects is driving our findings: (1) gender norms regarding women's political empowerment, (2) economic participation and opportunity, (3) educational attainment, and (4) health and survival in the country of ancestry. Those are different channels shaping the gender cultural attitudes that ultimately affect the reverse gender gap in volunteer activities.

This work is organized as follows: Section 2 presents the data used and our empirical strategy, Section 3 reports our main findings, robustness checks, identification analysis, and mechanisms, Sections 4 and 5 include our discussion and conclusion, respectively.

\section{Materials and Methods}

We gather the time devoted by individuals to volunteer activities from the 2006-2019 American Time Use Survey (ATUS) [23]. The time survey of the Bureau of Labor Statistics is 
nationally representative. Respondents report all their own performed activities and their duration throughout the $24 \mathrm{~h}$ of the previous day (from 4:00 a.m. to 4:00 a.m.) in addition to information on who was there while the activity was being performed and where the activity took place. With this detailed time survey, it is possible to calculate the time devoted to any given reference activity; in our case, we focus our attention on volunteer activities. We consider as volunteer activities those with an activity code between "150,000" and "159,999." These volunteer activities include administrative and support activities, social service and care activities (except medical), indoor and outdoor maintenance, building, clean-up activities, participating in performance and cultural activities, attending meetings, conferences, and training, public health and safety activities, waiting associated with volunteer activities, and security procedures related to volunteer activities. We calculate the total time devoted to volunteer activities as the sum of all episodes reported by respondents throughout the day.

Our main sample comprises early-arrival first- and second-generation immigrant workers living in the US, with 42 different countries of ancestry. The 42 countries of ancestry are all possible identifiable countries of ancestry in the ATUS with available information on the GGI after eliminating those countries of ancestry with fewer than 25 observations [17,21]. The sample is limited to individuals living in an identifiable US state. Our sample contains 7145 observations of workers aged 18 to 85 years. Following prior research [24], we include both generations of immigrants to ensure that we have enough observations to obtain reliable results. The early-arrival first generation is defined here as immigrants who arrived in the US at the age of 5 years or below and who report their country of origin (country of birth). Second-generation immigrants are US native individuals whose father or mother was not born in the US. We consider the mother's country of origin when there are discrepancies in the country of origin between parents. This approach is in line with the literature pointing to the mother's culture as an important factor in the intergenerational transmission of gender roles [25]. The two generations are almost identical because they have been exposed to US economic conditions, laws, and institutions for almost their entire lives and are unlikely to be affected by language barriers [17].

To capture the gender equality in an immigrant's country of ancestry, we use the 2006-2019 Gender Gap Index (GGI) (World Economic Forum). This index is a national-level indicator variable of gender equality that has been widely used in the literature on gender roles during recent years $[19,21,22]$. For each country-year, the GGI spans from zero to one and measures the relative position of women in a society, with larger values indicating higher gender equality. The GGI is the average of four sub-index scores (see a description in the Appendix A, Table A2: Gender Gap Educational Attainment, Gender Gap Economic Participation and Opportunity, Global Gender Gap Health and Survival, and Gender Gap Political Empowerment).

Summary statistics of the time devoted to volunteer activities and the cultural proxy are shown in Table 1. Choosing a sample of early-arrival first- and second-generation immigrants by country of ancestry, column (1) presents the reverse gender gap (women's time-men's time) in the time devoted to volunteer activities across countries of ancestry. On average, women spend $1.53 \mathrm{~min}$ per day more than men, but this difference varies considerably across countries of ancestry. Immigrant women from Ukraine underperform men in the time devoted to volunteer activities by $18 \mathrm{~min}$ per day, whereas women originating from Hungary overperform men by $30 \mathrm{~min}$. The rest of the columns show the value of the GGI and its sub-indexes by country of ancestry. The main cultural proxy, the GGI, averages 0.71 , with a standard deviation of 0.05 , ranging from 0.59 in Iran to 0.83 in Norway. At first glance, we do not observe a clear relationship between the reverse gender gap and the cultural proxy. 
Table 1. Summary statistics by country of ancestry.

\begin{tabular}{|c|c|c|c|c|c|c|c|}
\hline Country of Ancestry & $\begin{array}{l}\text { Reverse Gender Gap } \\
\text { in Time Devoted to } \\
\text { Volunteer Activities }\end{array}$ & GGI & GGI Pol. & $\begin{array}{c}\text { GGI Ec. } \\
\text { Opp. }\end{array}$ & $\begin{array}{c}\text { GGI } \\
\text { Health }\end{array}$ & GGI Educ. & Obs \\
\hline Ukraine & -17.74 & 0.69 & 0.08 & 0.72 & 0.98 & 1.00 & 42 \\
\hline Russia & -14.00 & 0.70 & 0.08 & 0.73 & 0.98 & 1.00 & 82 \\
\hline Panama & -9.31 & 0.72 & 0.19 & 0.70 & 0.98 & 0.99 & 45 \\
\hline Jamaica & -8.39 & 0.71 & 0.13 & 0.73 & 0.98 & 1.00 & 100 \\
\hline Vietnam & -6.76 & 0.69 & 0.12 & 0.73 & 0.95 & 0.95 & 87 \\
\hline Spain & -6.35 & 0.74 & 0.37 & 0.63 & 0.97 & 1.00 & 65 \\
\hline France & -5.97 & 0.73 & 0.28 & 0.66 & 0.98 & 1.00 & 93 \\
\hline Netherlands & -4.86 & 0.75 & 0.33 & 0.70 & 0.97 & 1.00 & 75 \\
\hline Germany & -3.84 & 0.76 & 0.38 & 0.71 & 0.98 & 0.99 & 668 \\
\hline Nigeria & -3.51 & 0.63 & 0.08 & 0.66 & 0.96 & 0.81 & 26 \\
\hline United Kingdom & -2.97 & 0.75 & 0.32 & 0.71 & 0.97 & 1.00 & 391 \\
\hline Korea & -2.27 & 0.64 & 0.10 & 0.52 & 0.97 & 0.95 & 149 \\
\hline Norway & -2.00 & 0.83 & 0.55 & 0.81 & 0.97 & 1.00 & 31 \\
\hline Mexico & -1.95 & 0.68 & 0.22 & 0.53 & 0.98 & 0.99 & 2118 \\
\hline Ecuador & -1.94 & 0.72 & 0.26 & 0.63 & 0.98 & 0.99 & 51 \\
\hline Colombia & -1.16 & 0.71 & 0.17 & 0.70 & 0.98 & 1.00 & 103 \\
\hline Italy & -0.70 & 0.69 & 0.20 & 0.58 & 0.97 & 0.99 & 408 \\
\hline Brazil & -0.21 & 0.68 & 0.09 & 0.64 & 0.98 & 0.99 & 31 \\
\hline Honduras & 0.00 & 0.69 & 0.16 & 0.61 & 0.98 & 1.00 & 35 \\
\hline Nicaragua & 0.00 & 0.75 & 0.41 & 0.59 & 0.98 & 1.00 & 38 \\
\hline Trinidad and Tobago & 0.00 & 0.72 & 0.21 & 0.69 & 0.98 & 0.99 & 31 \\
\hline Argentina & 0.00 & 0.72 & 0.31 & 0.60 & 0.98 & 1.00 & 38 \\
\hline Portugal & 0.00 & 0.72 & 0.21 & 0.70 & 0.97 & 0.99 & 62 \\
\hline El Salvador & 2.08 & 0.68 & 0.19 & 0.58 & 0.98 & 0.99 & 121 \\
\hline Canada & 2.14 & 0.74 & 0.22 & 0.76 & 0.97 & 1.00 & 527 \\
\hline Poland & 2.18 & 0.71 & 0.19 & 0.66 & 0.98 & 1.00 & 138 \\
\hline Greece & 2.25 & 0.68 & 0.11 & 0.64 & 0.98 & 0.99 & 86 \\
\hline Ireland & 2.63 & 0.78 & 0.42 & 0.72 & 0.97 & 1.00 & 126 \\
\hline China & 3.09 & 0.68 & 0.15 & 0.66 & 0.93 & 0.97 & 215 \\
\hline Austria & 4.34 & 0.72 & 0.28 & 0.63 & 0.98 & 0.99 & 51 \\
\hline Dominican Republic & 4.46 & 0.68 & 0.12 & 0.63 & 0.98 & 0.99 & 95 \\
\hline Japan & 4.56 & 0.65 & 0.07 & 0.58 & 0.98 & 0.99 & 151 \\
\hline Philippines & 4.69 & 0.77 & 0.34 & 0.78 & 0.98 & 1.00 & 253 \\
\hline Thailand & 5.45 & 0.70 & 0.07 & 0.74 & 0.98 & 0.99 & 41 \\
\hline Cuba & 6.84 & 0.74 & 0.35 & 0.62 & 0.97 & 1.00 & 209 \\
\hline Peru & 7.89 & 0.69 & 0.21 & 0.61 & 0.97 & 0.98 & 41 \\
\hline Guatemala & 8.31 & 0.64 & 0.09 & 0.56 & 0.98 & 0.94 & 53 \\
\hline Bahamas & 9.69 & 0.73 & 0.08 & 0.84 & 0.98 & 1.00 & 25 \\
\hline Iran & 16.45 & 0.59 & 0.03 & 0.39 & 0.97 & 0.96 & 39 \\
\hline Sweden & 19.69 & 0.81 & 0.50 & 0.79 & 0.97 & 1.00 & 29 \\
\hline India & 21.90 & 0.64 & 0.34 & 0.40 & 0.94 & 0.88 & 129 \\
\hline Hungary & 29.67 & 0.67 & 0.06 & 0.67 & 0.98 & 0.99 & 47 \\
\hline Average & 1.53 & 0.71 & 0.22 & 0.65 & 0.97 & 0.98 & \\
\hline Std. Dev. & 8.84 & 0.05 & 0.14 & 0.10 & 0.01 & 0.04 & \\
\hline
\end{tabular}

Notes: Data comes from the Integrated Public Use Microdata Series Time Use (IPUMS Time Use) for the period 2006-2019. The sample contains 7145 observations of early-arrival first- and second-generation immigrants, aged 18 to 85, originating from 42 different countries. Volunteering time is measured in minutes per day.

Figure 1 illustrates the association between the reverse gender gap in the time devoted to volunteer activities (sample: early-arrival first- and second-generation immigrants living in the US) and the average 2006-2019 GGI by country of ancestry. That figure suggests a possible negative relationship between the cultural proxy for gender equality in the country of ancestry and the reverse gender gap (women's time-men's time). Thus, the greater the culture of gender equality in the country of ancestry, the smaller the reverse gender 
gap in the time devoted to volunteer activities for both generations of immigrants. This observational evidence needs to be studied in greater depth in the next sections.

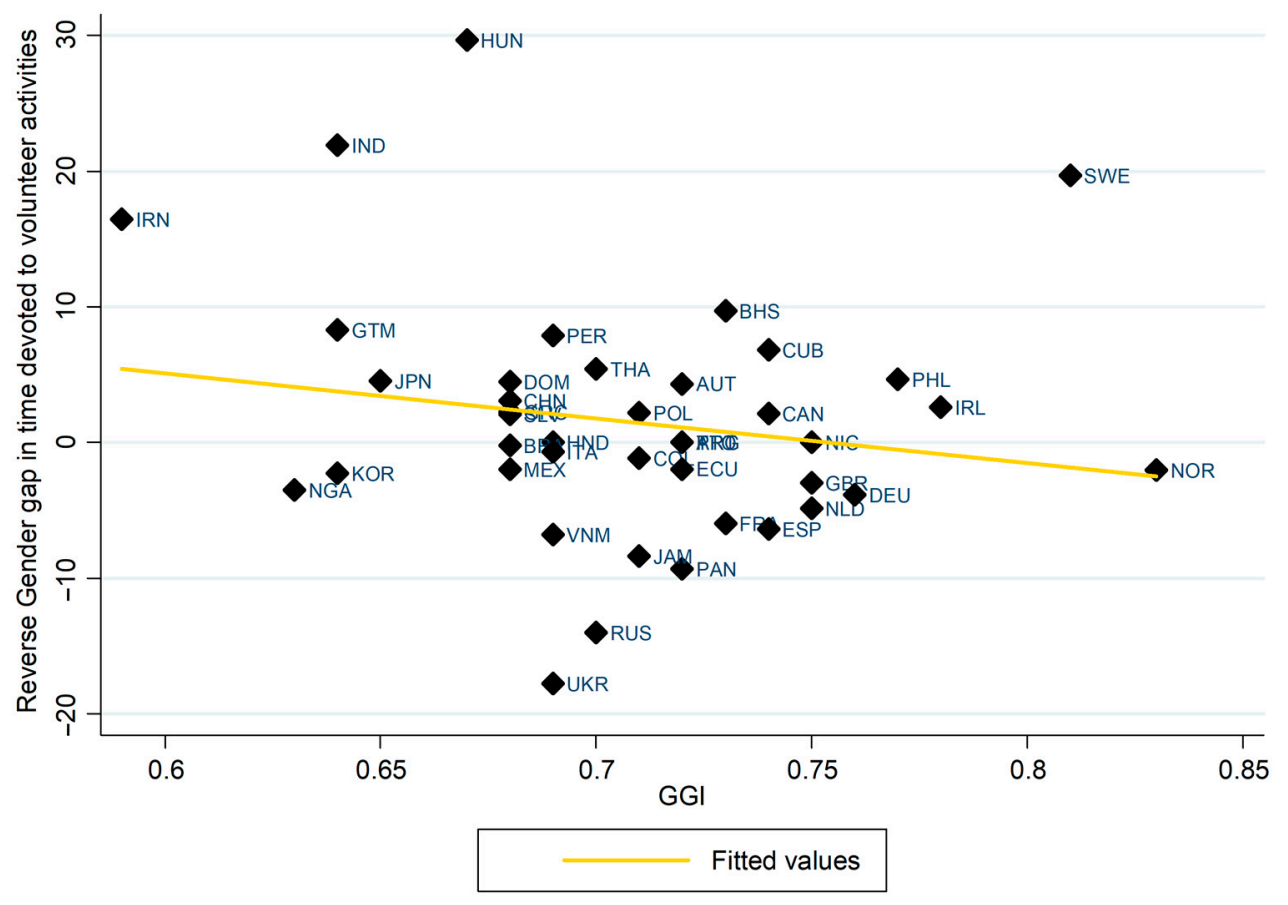

Figure 1. This figure plots the average reverse gender gap in time devoted to voluntary activities (women's time-men's time) and the average 2006-2019 GGI in each country of ancestry.

To gauge the impact of culture on the reverse gender gap in the time devoted to volunteer activities, our identification strategy is based on the epidemiological approach, which allows us to isolate the effect of culture from those of economic conditions and institutional factors by using a sample of early-arrival first- and second-generation immigrants living in the same host country. As all these individuals have spent almost their entire lives under the same US laws, markets, and institutions, the discrepancies among them in the time devoted to volunteer activities can be explained by cultural heritage differences. Thus, if the beliefs and preferences regarding women's role in society (traditional vs. gender equality) of their cultural background play a role in this setting and have been transmitted to them by their parents or other ancestors and/or their ethnic community, we would expect to find a relationship between the gender equality in the country of ancestry and the time that women relative to men devote to volunteer activities. Formally, we gauge this by estimating a Tobit model [26] on the time devoted to volunteer activities, which mitigates the possible problem of zero-inflated data of observations of the time devoted to volunteer activities:

$$
Y_{i j k t}^{*}=\beta_{1} \text { Female }_{i}+\beta_{2}\left(\text { Female }_{i^{*}} G \text { II }_{j t}\right)+X_{i j k t} \beta_{3}+\delta_{k}+\eta_{j}+\text { Female }_{i *} \delta_{k}+\theta_{t}+u_{i j k t}
$$

where $Y_{i j k t}^{*}$ is the unobservable latent variable, defined as:

$$
\begin{gathered}
Y_{i j k t}=Y_{i j k t}^{*} \text { if } Y_{i j k t}^{*}>0 \\
Y_{i j k t}=0 \text { if } Y_{i j k t}^{*} \leq 0
\end{gathered}
$$

with $Y_{i j k t}$ representing the daily minutes devoted to volunteer activities reported by worker $i$ of cultural origin $j$ living in state $k$ in year $t$. The variable Female $e_{i}$ is a dummy variable that takes the value one if the individual is a women and zero otherwise. $G G I_{j t}$ is the 
cultural proxy in the country of ancestry $j$ in year $t$ (for the cultural proxy, we use a contemporaneous measure, which is a common strategy in the literature [12]). The GGI is interpreted as follows: a higher value of this index indicates a more gender-equal culture. In this setting, to gauge the impact of culture, we exploit the cultural differences by country of origin of women relative to men. $\beta_{2}$ is the main coefficient of interest in the interaction between the $G G I_{j t}$ and the female indicator. This coefficient picks up the importance of culture in explaining the time devoted to volunteer activities of early-arrival first- and second-generation immigrant women over men (a similar empirical strategy is followed in $[19,21,22])$. We would expect $\beta_{2}$ to be negative, indicating that more gender-equal attitudes in the immigrant's country of ancestry are associated with a smaller reverse gender gap in the host country. The vector $X_{i j k t}$ includes a set of individual traits that may affect the time devoted to volunteer activities for reasons unrelated to culture. We include controls for age, educational level (more college or not), and race (white or not) (we have enlarged the set of demographic and socio-economic controls characteristics and our results are maintained; see results below). These individual characteristics are also interacted with the female indicator. Controls for unobserved characteristics of the place of residence are added by using state fixed effects, denoted by $\delta_{k}$. To control for country of ancestry traits that may be related to gender roles, we introduce country of ancestry fixed effects, $\eta_{j}$, while, to pick up the time-variant unobserved characteristics, we add year fixed effects, $\theta_{t}$. State fixed effects $\left(\delta_{k}\right)$ are interacted with Female $e_{i}$ to account for the variation in the state's gender differences in the time devoted to volunteer activities that may arise from dissimilarities across states in cultural/institutional channels. Standard errors are clustered at the country of ancestry level to account for any within-ethnicity correlation in the error terms. All the regressions are weighted using ATUS weights (all estimates have been repeated with/without weights and clusters; the results are maintained).

\section{Results}

\subsection{Main Results}

Table 2 shows the results obtained by estimating Equation (1). Column (1), which includes controls for the female indicator and the year, country of ancestry, and state fixed effects, indicates that women spend more time undertaking volunteer activities than men, pointing to the aforementioned reverse gender gap. To gauge the gender differential effect of culture, the interaction between the female dummy and the home-country cultural proxy is added in column (2). The results indicate a negative and statistically significant relationship between the interaction term and the time devoted to volunteer activities. Then, the more gender equality in the country of ancestry, the less time women spend volunteering relative to men. This suggests that the reverse gender gap in time spent on volunteer activities decreases among those originating from countries of ancestry with more egalitarian attitudes. With respect to the rest of controls, estimated coefficients point to a positive effect of age and high level of education on the time devoted to volunteer activities (see Table A1 in Appendix A that includes all controls). This is in line with the observational evidence pointing to a positive correlation between volunteerism and level of education [27]. As possible explanation, researchers indicate that education is translated into skills that increase the capacity to volunteer [27]. The positive effect of age is related to the findings on that volunteering changes across the life course, with a peak in middle age [28]. 
Table 2. Main results.

\begin{tabular}{lcc}
\hline Dependent Variable: Time Devoted to Volunteer Activities & $\mathbf{( 1 )}$ & $\mathbf{( 2 )}$ \\
\hline Female & $49.709^{* *}$ & $59.928^{* * *}$ \\
GGI $\times$ Female & $(20.494)$ & $(5.378)$ \\
& & $-296.656^{* * *}$ \\
\hline Year FE & & $(7.512)$ \\
Country of ancestry FE & Yes & Yes \\
State FE & Yes & Yes \\
State FE $\times$ Female & Yes & Yes \\
Observations & No & Yes \\
\hline
\end{tabular}

Notes: We estimate Equation (1). All regressions include a constant, as well as demographic controls for age, race and educational attainment. These individual characteristics are also interacted with the female indicator in column (2). The sample in all columns includes workers between 18 and 85 years old. Estimates are weighted using ATUS weights. Robust standard errors are clustered at the state level and reported in parentheses. *** Significant at the $1 \%$ level, ${ }^{* *}$ Significant at the $5 \%$ level.

For robustness purposes, we check the validity of our findings using different subsamples and after incorporating additional controls. The results are reported in Table 3. Our first simple robustness check consists of eliminating those with a Mexican origin. Mexico is the country of ancestry with the largest number of observations, which could be driving our estimations. Results are presented in column (1). It is still observed a negative relationship between the interaction term and the time-devoted to volunteer activities. To provide additional evidence in favor of our estimations, we repeat the regressions without the two countries with the highest and the lowest country of ancestry GGI (Norway and Iran) in column (2), but nothing changes. Again, the idea behind this simple robustness check is that to reinforce our empirical findings we should not observe a change in our conclusions after eliminating those individuals from extreme cultural countries. In column (3), we limit our sample to individuals aged 21 to 65 who are more likely to have similar allocation of time because they are likely to have completed schooling and are below the retirement age. The results remain unchanged.

To mitigate possible concerns about the omission of some traits of the individuals in the specifications, we extend the number of controls in column (4). We include controls for whether the respondent is married, a full-time worker, or a self-employed worker, whether she/he has children, whether she/he lives in a high-income family, the size of the MSA of residence, and the occupation and industry of the respondent's main job, which are found to be related to the time spent on volunteer activities [29-35] (the variation in the sample size is due to the lack of availability of information on family income for all the individuals in our sample; Table A1 in the Appendix A shows all the estimated coefficients). Our estimation on the variable of interest does not vary substantially. This specification allows us to explore some gender differences in the effects of employment and family characteristics. Being married, with children and having high income encourage men's volunteer activities. This can be explained by an increase in new contacts for married men that may function as channels to volunteering $[30,36]$. However, for women, the married situation may reduce their available time on volunteer activities [27]. Similarly, children may impose a time constraint for women to spend time in volunteer activities $[37,38]$ whereas for men having children can create new opportunities for volunteering for example in one's children's school [39]. For both full-time workers men and women, we find a clearly negative association with the time devoted to volunteer activities, which is consistent with prior evidence on that part-time workers have higher rates of volunteering than full-time workers [30]. Note that because the inclusion of some of these controls can generate some endogeneity concerns, we prefer not to include them in our main analysis. In any case, even with these possible endogeneity concerns, it is comforting that our findings are maintained. 
Table 3. Robustness checks adding more controls, using different subsamples and alternative methodologies.

\begin{tabular}{|c|c|c|c|c|c|c|}
\hline $\begin{array}{l}\text { Dependent Variable: } \\
\text { Time Devoted to } \\
\text { Volunteer Activities }\end{array}$ & (1) & (2) & (3) & (4) & (5) & (6) \\
\hline Female & $\begin{array}{c}1506.245^{* * *} \\
(4.111)\end{array}$ & $\begin{array}{c}-21.829 * * * \\
(5.365)\end{array}$ & $\begin{array}{c}-214.853^{* * *} \\
(5.436)\end{array}$ & $\begin{array}{c}112.105^{* * *} \\
(5.632)\end{array}$ & $\begin{array}{c}158.813^{* * *} \\
(5.121)\end{array}$ & $\begin{array}{l}5.467 * \\
(3.274)\end{array}$ \\
\hline GGI $\times$ Female & $\begin{array}{c}-507.066^{* * *} \\
(5.633)\end{array}$ & $\begin{array}{c}-166.001^{* * *} \\
(7.463)\end{array}$ & $\begin{array}{c}-106.169^{* * *} \\
(7.606)\end{array}$ & $\begin{array}{c}-292.553^{* * *} \\
(7.838)\end{array}$ & $\begin{array}{c}-441.708^{* * *} \\
(7.174)\end{array}$ & $\begin{array}{c}-8.936^{* * *} \\
(3.390)\end{array}$ \\
\hline Year FE & Yes & Yes & Yes & Yes & Yes & Yes \\
\hline Country of ancestry FE & Yes & Yes & Yes & Yes & Yes & Yes \\
\hline State FE & Yes & Yes & Yes & Yes & Yes & Yes \\
\hline State FE $\times$ Female & Yes & Yes & Yes & Yes & Yes & Yes \\
\hline Observations & 5027 & 7075 & 6278 & 6892 & 7126 & 7126 \\
\hline
\end{tabular}

Notes: We estimate Equation (1) in columns (1-5). We run an ordered logit model in column (6). All regressions include a constant, as well as demographic and controls for age, race and educational attainment. These individual characteristics are also interacted with the female indicator. The sample includes workers between 18 and 85 years old in all columns except in column (3). Specification in column (1) excludes first- and second-immigrants from Mexico, and those from Norway and Iran are excluded in column (2). The sample in column (3) includes workers between 21 and 65 years. Specification in column (4) includes controls for whether the respondent is married, fulltime worker, self-employed worker, whether she/he has children, lives in a high-income family, the size of the MSA of residence and their occupation and industry of their main job. Variation in the sample size is due to the no availability of information on family income for all individuals in our sample. Specification in columns (5) and (6) includes the GDP per capita (in constant 2010 USD) of the country of ancestry and its interaction with the female dummy. Estimates are weighted using ATUS weights. Robust standard errors are clustered at the state level and reported in parentheses. ${ }^{* * *}$ Significant at the $1 \%$ level, ${ }^{*}$ Significant at the $10 \%$ level.

Another potential concern with our analysis is that we might erroneously interpret our results as evidence of culture if unobserved attributes at the country of ancestry level are correlated with the cultural proxy. To determine whether omitted variables are likely to severely bias our results, we follow the literature in adding home-country aggregate variables. Specifically, we include the GDP per capita (in constant 2010 US dollars) as a supplementary control of the countries of ancestry characteristics when running our main regression in column (5) (we also interact the GDP per capita with the female indicator and nothing changes; the data come from the World Bank). Our findings do not vary. The use of alternative methodologies can also provide further evidence in favor of the cultural impact. Taking this into account, we run an ordered logit model in column (6). The time devoted to volunteer activities is converted into a categorical variable taking values from 1 to 4 on the basis of the time at 25th, 50th and 75th percentiles of the distribution and our conclusions do not change. It is reassuring that our results are maintained after running all these simple robustness checks.

\subsection{Identification: How Can Culture Be Transmitted?}

To be able to identify the impact of culture, that culture needs to be transmitted through a family channel (vertical or intergenerational transmission) and/or within the ethnic communities in which immigrants live (horizontal transmission or peer effects). The family channel cannot be checked appropriately with the dataset that we have here. We do not know, for example, whether the parents of our sample of immigrants behave in a similar way. However, we intend to test the possible horizontal transmission of culture by exploring whether living close to a high proportion of individuals with the same origin encourages the cultural-origin-related behavior of both early-first- and second-generation immigrants. We follow [22] and calculate the proportion of individuals from the same country of ancestry in each state. Then, we split the sample between those who are above and below the mean of concentration of individuals with the same ethnicity and re-run our estimations. As can be seen in columns (1) and (2) of Table 4, the effect of culture on early-arrival first- and second-generation immigrants' predicted outcome is considerably larger for those living in states with a high concentration of immigrants from the same ethnicity, which provides support for the horizontal transmission of culture. This evidence 
confirms our identification strategy of culture as a factor determining the reverse gender gap in the time devoted to volunteer activities.

Table 4. Transmission of culture.

\begin{tabular}{lcc}
\hline $\begin{array}{l}\text { Dependent Variable: Time } \\
\text { Devoted to Volunteer Activities }\end{array}$ & $\begin{array}{c}(\mathbf{1}) \\
\text { Concentration Same } \\
\text { Ethnicity above the Mean }\end{array}$ & $\begin{array}{c}\text { (2) } \\
\text { Concentration Same } \\
\text { Ethnicity below the Mean }\end{array}$ \\
\hline Female & $\begin{array}{c}1023.044^{* * *} \\
(1.718) \\
\text { GGI } \times \text { Female }\end{array}$ & $\begin{array}{c}137.788^{* * *} \\
(4.147)\end{array}$ \\
& $(2.724)$ & $-303.511^{* * *}$ \\
Year FE & Yes & $(5.717)$ \\
Country of ancestry FE & Yes & Yes \\
State FE & Yes & Yes \\
State FE $\times$ Female & 1946 & Yes \\
Observations & Yes \\
Notes: We estimate Equation (1). All regressions include a constant, as well as demographic controls for age, \\
race and educational attainment. These individual characteristics are also interacted with the female indicator. \\
$\begin{array}{l}\text { Columns (1) and (2) include first- and second-generation of immigrants living in states where the concentration of } \\
\text { individuals of their same country of ancestry is above and below the mean of the proportion of individuals of the } \\
\text { same ethnicity, respectively. Estimates are weighted using ATUS weights. Robust standard errors are clustered at } \\
\text { the state level and reported in parentheses. }{ }^{* * *} \text { Significant at the 1\% level. }\end{array}$
\end{tabular}

\subsection{Mechanisms Shaping the Culture from the Country of Ancestry}

Thus far, our findings suggest that culture may explain, at least in part, the overperformance of women in the time devoted to volunteer activities. We now supplement this analysis by examining the channels/mechanisms in the country of ancestry that are shaping the gender cultural attitudes that ultimately affect the gender gap in volunteer activities. Accordingly, we separate each of the sub-indexes composing the GGI: Gender Gap Educational Attainment, Gender Gap Economic Participation and Opportunity, Global Gender Gap Health and Survival, and Gender Gap Political Empowerment. As each of these sub-indexes captures a different aspect of culture, they may explain the reverse gender gap in volunteer activities in different ways.

The results point to the four cultural aspects as drivers of the country of ancestry culture responsible for the gender differences in time devoted to volunteer activities; see Table 5. This provides extra empirical evidence in favor of our findings on the effect of culture on the gender differences in the time devoted to volunteer activities. The more traditional the roles, the greater the reverse gender differences in the time devoted to volunteer activities.

Table 5. Mechanisms shaping the culture from the country of ancestry.

\begin{tabular}{lcccc}
\hline $\begin{array}{l}\text { Dependent Variable: } \\
\text { Time Devoted to } \\
\text { Volunteer Activities }\end{array}$ & $\mathbf{( 1 )}$ & $\mathbf{( 2 )}$ & $\mathbf{( 3 )}$ & $\mathbf{( 4 )}$ \\
\hline Female & $-120.155^{* * *}$ & $-133.235^{* * *}$ & $645.500^{* * * *}$ & $1585.906^{* * *}$ \\
GGI pol. $\times$ Female & $(4.952)$ & $(5.152)$ & $(5.247)$ & $(5.028)$ \\
GGI Ec. Opp $\times$ Female & $-115.882^{* * *}$ & & & \\
GGI educ. $\times$ Female & $(14.754)$ & $-19.348^{* *}$ & & \\
GGI health $\times$ Female & & & $-810.378^{* * *}$ & $(5.313)$ \\
\end{tabular}


Table 5. Cont.

\begin{tabular}{lcccc}
\hline $\begin{array}{l}\text { Dependent Variable: } \\
\text { Time Devoted to } \\
\text { Volunteer Activities }\end{array}$ & $\mathbf{( 1 )}$ & $\mathbf{( 2 )}$ & $\mathbf{( 3 )}$ & (4) \\
\hline Year FE & Yes & Yes & Yes & Yes \\
Country of ancestry FE & Yes & Yes & Yes & Yes \\
State FE $\times$ Female & Yes & Yes & Yes & Yes \\
State FE $\times$ Female & Yes & Yes & Yes & Yes \\
Observations & 7145 & 7145 & 7145 & 7145 \\
\hline
\end{tabular}

Notes: We estimate Equation (1). All regressions include a constant, as well as demographic controls for age, race and educational attainment. These individual characteristics are also interacted with the female indicator. Estimates are weighted using ATUS weights. Robust standard errors are clustered at the state level and reported in parentheses. *** Significant at the $1 \%$ level, ${ }^{* *}$ Significant at the $5 \%$ level.

\section{Discussion}

With this work, we aim to fill the literature gap on the study of a possible causal link between culture and volunteer activities. We separate the effects of laws, economic conditions, and institutions from that of culture in determining gender differences in the time devoted to volunteer activities by following the epidemiological approach. Accordingly, we merge data from the 2006-2019 American Time Use Survey on early-arrival firstand second-generation immigrants living in the United States with their corresponding annual country of ancestry's Gender Gap Index (GGI). Our identification strategy is based on both generations of immigrants being exposed to the same laws, institutions, and economic conditions in the US but also being influenced by different cultural heritages, which allows us to exploit their cultural differences as a factor explaining the time devoted to volunteer activities.

Our results show that gender equality reduces the reverse gender gap in volunteer activities. We find that the more gender equality in the country of ancestry, the less time women spend volunteering relative to men. Results are robust to the use of alternative samples, the inclusion/exclusion of several controls, and the use of alternative methodologies. Additionally, we show empirical evidence on that beliefs transmitted to early-arrival firstand second-generation immigrants regarding women's political empowerment, economic participation and opportunity, educational attainment, and health and survival in the country of ancestry are all channels that shape the gender cultural attitudes that ultimately affect the reverse gender gap in volunteer activities.

The estimated causal effect of culture in determining the time devoted to volunteer activities is in line with the observational evidence pointing to differences in institutional and cultural context as a factor determining the cross-country differences $[28,40]$. As in prior research, our results suggest that culture plays a role in this setting but differences in volunteering cannot be fully explained by differences in social and cultural factors $[4,41]$.

\section{Conclusions}

The evidence provided in this work points to the importance of the gender equality cultural differences among countries in explaining, at least in part, the cross-country differences in the reverse gender gap in volunteer activities. Although volunteering is considered to be a global vehicle for sustainable development (2030 UN Agenda for Sustainable Development), this activity hides a reverse gender gap resulting from traditional gender roles. Our policy recommendation in this setting focuses on that cultural differences should be considered on the political agenda when designing and applying specific measures that promote volunteering; otherwise, these activities can penalize women in achieving gender equality. This is also one of the sustainable development goals (number 5), which states that: "achieving gender equality and empowering all women and girls is crucial for sustainable development." Volunteering is a vehicle for sustainable development that cannot be a charge for women. 
Author Contributions: Conceptualization, H.B., M.M. (Miriam Marcén) and M.M. (Marina Morales); methodology, H.B., M.M. (Miriam Marcén) and M.M. (Marina Morales); software, H.B., M.M. (Miriam Marcén) and M.M. (Marina Morales); validation, H.B., M.M. (Miriam Marcén) and M.M. (Marina Morales); formal analysis, H.B., M.M. (Miriam Marcén) and M.M. (Marina Morales); investigation, H.B., M.M. (Miriam Marcén) and M.M. (Marina Morales); resources, H.B., M.M. (Miriam Marcén) and M.M. (Marina Morales); data curation, H.B., M.M. (Miriam Marcén) and M.M. (Marina Morales); writing—original draft preparation, H.B., M.M. (Miriam Marcén) and M.M. (Marina Morales); writing—review and editing, H.B., M.M. (Miriam Marcén) and M.M. (Marina Morales); visualization, H.B., M.M. (Miriam Marcén) and M.M. (Marina Morales); supervision, H.B., M.M. (Miriam Marcén) and M.M. (Marina Morales); project administration, H.B., M.M. (Miriam Marcén) and M.M. (Marina Morales); funding acquisition, H.B., M.M. (Miriam Marcén) and M.M. (Marina Morales) All authors have read and agreed to the published version of the manuscript.

Funding: This research has been funded by the Regional Government of Aragon and the European Fund of Regional Development (Grant S32_20R). This research has been funded by the Ministerio de Ciencia e Innovación (Grant number: PID2020-114354RA-I00).

Institutional Review Board Statement: Not applicable.

Informed Consent Statement: Not applicable.

Data Availability Statement: Data from the American Time Use Survey (ATUS) is available at https:/ / www.atusdata.org/atus / (accessed on 1 March 2021). The World Economic Forum's gender gap index (GGI) is available at https:/ /tcdata360.worldbank.org/indicators/af52ebe9? country= BRA\&indicator=27959\&viz=line_chart\&years=2006,2020 (accessed on 1 March 2021).

Conflicts of Interest: The authors declare no conflict of interest.

\section{Appendix A}

Table A1. Robustness checks adding more controls showing all estimated coefficients.

\begin{tabular}{ll}
\hline Dependent Variable: Time Devoted to Volunteer Activities & \multicolumn{1}{c}{$(\mathbf{1})$} \\
\hline Female & $112.105^{* * *}$ \\
GGI $\times$ Female & $(5.632)$ \\
Age & $-292.553^{* * *}$ \\
Age $\times$ Female & $(7.838)$ \\
More college & $2.810^{* * *}$ \\
& $(0.018)$ \\
More college $\times$ Female & $1.107^{* * *}$ \\
White & $(0.111)$ \\
White $\times$ Female & $56.114^{* * *}$ \\
Married & $(2.014)$ \\
Married $\times$ Female & $12.019^{* *}$ \\
Having Children & $(5.318)$ \\
Having Children $\times$ Female & $2.476^{* * *}$ \\
Fulltime worker & $(0.796)$ \\
& $-68.376^{* * *}$ \\
\hline
\end{tabular}


Table A1. Cont.

\begin{tabular}{|c|c|}
\hline Dependent Variable: Time Devoted to Volunteer Activities & (1) \\
\hline Fulltime worker $\times$ Female & $\begin{array}{l}-67.405^{* * *} \\
(5.121)\end{array}$ \\
\hline Self-employed & $\begin{array}{l}-49.751 * * * \\
(3.391)\end{array}$ \\
\hline Self-employed $\times$ Female & $\begin{array}{l}119.568^{* * *} \\
(6.868)\end{array}$ \\
\hline High Income Family & $\begin{array}{l}2.730 \\
(2.700)\end{array}$ \\
\hline High Income Family $\times$ Female & $\begin{array}{l}-3.446 \\
(6.564)\end{array}$ \\
\hline MSA size: $100,000-249,999$ & $\begin{array}{l}29.018^{* * *} \\
(3.794)\end{array}$ \\
\hline MSA size: $250,000-499,999$ & $\begin{array}{l}-24.883^{* * *} \\
(3.883)\end{array}$ \\
\hline MSA size: 500,000-999,999 & $\begin{array}{l}-52.169 * * * \\
(5.345)\end{array}$ \\
\hline MSA size: 1,000,000-2,499,999 & $\begin{array}{l}-24.816^{* * *} \\
(3.136)\end{array}$ \\
\hline MSA size: 2,500,000-4,999,999 & $\begin{array}{l}23.906^{* * *} \\
(4.898)\end{array}$ \\
\hline MSA size: $5,000,000+$ & $\begin{array}{l}7.100 * \\
(4.121)\end{array}$ \\
\hline Service Occupations & $\begin{array}{l}-71.365^{* * *} \\
(4.755)\end{array}$ \\
\hline Sales and Office Occupations & $\begin{array}{l}-29.946^{* * * *} \\
(3.530)\end{array}$ \\
\hline Natural Resources, Construction, and Maintenance Occupations & $\begin{array}{l}-59.389 * * * \\
(4.710)\end{array}$ \\
\hline Production, Transportation, and Material Moving Occupations & $\begin{array}{l}-48.938^{* * *} \\
(3.246)\end{array}$ \\
\hline Construction & $\begin{array}{l}-205.488^{* * * *} \\
(2.906)\end{array}$ \\
\hline Manufacturing & $\begin{array}{l}-249.952 * * * \\
(2.700)\end{array}$ \\
\hline Wholesale Trade & $\begin{array}{l}-258.659 * * * \\
(3.387)\end{array}$ \\
\hline Retail Trade & $\begin{array}{l}-225.761 * * * \\
(4.055)\end{array}$ \\
\hline Transportation and Warehousing and Utilities & $\begin{array}{l}-177.250 * * * \\
(3.720)\end{array}$ \\
\hline Information & $\begin{array}{l}-274.112 * * * \\
(2.532)\end{array}$ \\
\hline Finance and Insurance, and Real Estate, and Rental and Leasing & $\begin{array}{l}-214.429 * * * \\
(3.254)\end{array}$ \\
\hline Professional and business services & $\begin{array}{l}-223.190 * * * \\
(2.717)\end{array}$ \\
\hline Educational Services, and Health Care and Social Assistance & $\begin{array}{l}-187.278^{* * *} \\
(2.452)\end{array}$ \\
\hline Arts, Entertainment, and Recreation, and Accommodation and Food Services & $\begin{array}{l}-189.366^{* * * *} \\
(4.248)\end{array}$ \\
\hline Other Services, Except Public Administration & $\begin{array}{l}-146.514 * * * \\
(2.563)\end{array}$ \\
\hline Public Administration & $\begin{array}{l}-242.455^{* * *} \\
(2.642)\end{array}$ \\
\hline
\end{tabular}


Table A1. Cont.

\begin{tabular}{lc}
\hline Dependent Variable: Time Devoted to Volunteer Activities & (1) \\
\hline Year FE & Yes \\
Country of ancestry FE & Yes \\
State FE & Yes \\
State FE $\times$ Female & Yes \\
Observations & 6892 \\
\hline Notes: We estimate Equation (1). The sample includes workers between 18 and 85 years old in all columns All \\
regressions include a constant, as well as demographic controls for age, race and educational attainment, for \\
whether the respondent is married, fulltime worker, self-employed worker, whether she/he has children, lives \\
in a high-income family, the size of the MSA of residence and their occupation and industry of their main job. \\
Variation in the sample size is due to the no availability of information on family income for all individuals \\
in our sample. These individual characteristics are also interacted with the female indicator. Estimates are \\
weighted using ATUS weights. Robust standard errors are clustered at the state level and reported in parentheses. \\
$* * *$ Significant at the $1 \%$ level, ${ }^{* *}$ Significant at the $5 \%$ level, ${ }^{*}$ Significant at the $10 \%$ level.
\end{tabular}

Table A2. Gender Equality Measures.

\begin{tabular}{clc}
\hline Name & \multicolumn{1}{c}{ Definition } & Source \\
\hline & $\begin{array}{l}\text { Measures the gap between men and women in four } \\
\text { fundamental categories: economic opportunities, economic }\end{array}$ & World Economic Forum, 2021 \\
participation, educational attainment, political & Report \\
achievements, health and survival. The highest possible & score is 1 (equality) and the lowest possible score is 0 \\
(inequality).
\end{tabular}

Index based upon gender differences in the participation in labor markets, wage equality and the gap between the advancement of women and men captured through the ratio of women to men among legislators, senior officials and managers, and the ratio of women to men among technical and professional workers. The highest possible score is 1 (equality) and the lowest possible score is 0 (inequality). This index is also elaborated for the World Economic Forum as part of the Gender Gap Index.

Index based upon the gap between women's and men's current access to education through ratios of women to men Educational Attainment in primary, secondary and tertiary level of education. The Sub-index highest possible score is 1 (equality) and the lowest possible score is 0 (inequality). This index is also elaborated for the World Economic Forum as part of the Gender Gap Index.

World Economic Forum, 2021 Report

World Economic Forum, 2021 Report
Index based upon the differences between women's and men's health through the use of the sex ratio at birth and the

Health and Survival Sub-index gap between women's and men's healthy life expectancy. The highest possible score is 1 (equality) and the lowest possible score is 0 (inequality). This index is also elaborated for the World Economic Forum as part of the Gender Gap Index.
Index based upon the gap between men and women at the highest level of political decision-making by using the ratio of women to men in positions of minister and the ratio of women to men in parliamentary positions. The highest possible score is 1 (equality) and the lowest possible score is 0 (inequality). This index is also elaborated for the World Economic Forum as part of the Gender Gap Index.
World Economic Forum, 2021 Report

World Economic Forum, 2021 Report Sub-index 


\section{References}

1. Wilson, J. Volunteering. Annu. Rev. Sociol. 2000, 26, 215-240. [CrossRef]

2. Carpenter, J.; Myers, C.K. Why Volunteer? Evidence on the Role of Altruism, Image, and Incentives. J. Public Econ. 2010, 94, 911-920. [CrossRef]

3. Wemlinger, E.; Berlan, M.R. Does Gender Equality Influence Volunteerism? A Cross-National Analysis of Women's Volunteering Habits and Gender Equality. Voluntas 2016, 27, 853-873. [CrossRef]

4. Gil-Lacruz, A.I.; Marcuello, C.; Saz-Gil, M.I. Gender Differences in European Volunteer Rates. J. Gend. Stud. 2019, 28 , 127-144. [CrossRef]

5. Fernández, R. Does Culture Matter? In Handbook of Social Economics; Benhabib, J., Bisin, A., Jackson, M.O., Eds.; Elsevier B.V.: Amsterdam, The Netherlands, 2011; Volume 1, pp. 481-510. [CrossRef]

6. Giuliano, P. Review of Cultural Evolution: Society, Technology, Language, and Religion Edited by Peter J. Richerson and Morten H. Christiansen. J. Econ. Lit. 2016, 54, 522-533. [CrossRef]

7. Giuliano, P. Living Arrangements in Western Europe: Does Cultural Origin Matter? J. Eur. Econ. Assoc. 2007, 5, 927-952. [CrossRef]

8. Marcén, M.; Morales, M. Live Together: Does Culture Matter? Rev. Econ. Househ. 2019, 17, 671-713. [CrossRef]

9. Bellido, H.; Marcén, M.; Molina, J.A. The Effect of Culture on Fertility Behavior of US Teen Mothers. Fem. Econ. 2016, 22, 101-126. [CrossRef]

10. Contreras, D.; Plaza, G. Cultural Factors in Women's Labor Force Participation in Chile. Fem. Econ. 2010, 16, 27-46. [CrossRef]

11. Fernández, R.; Fogli, A. Fertility: The Role of Culture and Family Experience. J. Eur. Econ. Assoc. 2006, 4, 552-561. [CrossRef]

12. Fernández, R.; Fogli, A. Culture: An Empirical Investigation of Beliefs, Work, and Fertility. Am. Econ. J. Macroecon. 2009, 1, 146-177. [CrossRef]

13. Marcén, M.; Molina, J.A.; Morales, M. The Effect of Culture on the Fertility Decisions of Immigrant Women in the United States. Econ. Model. 2018, 70, 15-28. [CrossRef]

14. Marcén, M. The Role of Culture on Self-Employment. Econ. Model. 2014, 44, S20-S32. [CrossRef]

15. Eugster, B.; Lalive, R.; Steinhauer, A.; Zweimüller, J. Culture, Work Attitudes, and Job Search: Evidence from the Swiss Language Border. J. Eur. Econ. Assoc. 2017, 15, 1056-1100. [CrossRef]

16. Fernández, R. Women, Work, and Culture. J. Eur. Econ. Assoc. 2007, 5, 305-332. [CrossRef]

17. Furtado, D.; Marcén, M.; Sevilla, A. Does Culture Affect Divorce? Evidence From European Immigrants in the United States. Demography 2013, 50, 1013-1038. [CrossRef] [PubMed]

18. Marcén, M.; Morales, M. The Effect of Culture on Home-Ownership. J. Reg. Sci. 2020, 60, 56-87. [CrossRef]

19. Marcén, M.; Morales, M. Gender Division of Household Labor: How Does Culture Operate? Available online: https://www. econstor.eu/handle/10419/201505 (accessed on 1 March 2021).

20. Blau, F.D.; Kahn, L.M.; Comey, M.; Eng, A.; Meyerhofer, P.; Willén, A. Culture and Gender Allocation of Tasks: Source Country Characteristics and the Division of Non-Market Work among US Immigrants. Rev. Econ. Househ. 2020, 18, 907-958. [CrossRef]

21. Nollenberger, N.; Rodríguez-Planas, N.; Sevilla, A. The Math Gender Gap: The Role of Culture. Am. Econ. Rev. 2016, 106, $257-261$. [CrossRef]

22. Rodríguez-Planas, N.; Nollenberger, N. Let the Girls Learn! It Is Not Only about Math ... It's about Gender Social Norms. Econ. Educ. Rev. 2018, 62, 230-253. [CrossRef]

23. Hofferth, S.L.; Flood, S.M.; Sobek, M. American Time Use Survey Data Extract Builder: Version 2.7 [Dataset]; IPUMS; University of Maryland: College Park, MD, USA; University of Minnesota: Minneapolis, MN, USA, 2018. [CrossRef]

24. González, L.; Rodríguez-Planas, N. Gender Norms and Intimate Partner Violence. J. Econ. Behav. Organ. 2020, 178, 223-248. [CrossRef]

25. Blau, F.D.; Kahn, L.M.; Liu, A.Y.H.; Papps, K.L. The Transmission of Women's Fertility, Human Capital, and Work Orientation across Immigrant Generations. J. Popul. Econ. 2013, 26, 405-435. [CrossRef]

26. Tobin, J. Estimation of Relationships for Limited Dependent Variables. Econometrica 1958, 26, 24. [CrossRef]

27. Lancee, B.; Radl, J. Volunteering over the Life Course. Soc. Forces 2014, 93, 833-862. [CrossRef]

28. Wilson, J. Volunteerism Research: A Review Essay. Nonprofit Volunt. Sect. Q. 2012, 41, 176-212. [CrossRef]

29. Webb, N.J.; Abzug, R. Do Occupational Group Members Vary in Volunteering Activity? Nonprofit Volunt. Sect. Q. 2008, 37, 689-708. [CrossRef]

30. Rotolo, T.; Wilson, J. Employment Sector and Volunteering: The Contribution of Nonprofit and Public Sector Workers to the Volunteer Labor Force. Sociol. Q. 2006, 47, 21-40. [CrossRef]

31. Holt, S.B. Giving Time: Examining Sector Differences in Volunteering Intensity. J. Public Adm. Res. Theory 2020, 30, 22-40. [CrossRef]

32. Mesch, D.J.; Rooney, P.M.; Steinberg, K.S.; Denton, B. The Effects of Race, Gender, and Marital Status on Giving and Volunteering in Indiana. Nonprofit Volunt. Sect. Q. 2006, 35, 565-587. [CrossRef]

33. Mutchler, J.E.; Burr, J.A.; Caro, F.G. From Paid Worker to Volunteer: Leaving the Paid Workforce and Volunteering in Later Life. Soc. Forces 2003, 81, 1267-1293. [CrossRef]

34. Sundeen, R.A. Family Life Course Status and Volunteer Behavior: Implications for the Single Parent. Sociol. Perspect. 1990, 33, 483-500. [CrossRef] 
35. Hayghe, H.V. Volunteers in the U.S.: Who Donates the Time. Mon. Labor Rev. 1991, 114, 17.

36. Tang, F. What Resources Are Needed for Volunteerism? A Life Course Perspective. J. Appl. Gerontol. 2006, 25, 375-390. [CrossRef]

37. Nesbit, R. The Influence of Major Life Cycle Events on Volunteering. Nonprofit Volunt. Sect. Q. 2012, 41, 1153-1174. [CrossRef]

38. Taniguchi, H. Men's and Women's Volunteering: Gender Differences in the Effects of Employment and Family Characteristics. Nonprofit Volunt. Sect. Q. 2006, 35, 83-101. [CrossRef]

39. Gee, L.K. The Nature of Giving Time to Your Child's School. Nonprofit Volunt. Sect. Q. 2011, 40, 552-565. [CrossRef]

40. Fiorillo, D.; Nappo, N. Formal and Informal Volunteering and Health across European Countries. Available online: https: / /ideas.repec.org/p/zbw / esprep/104062.html (accessed on 1 March 2021).

41. Plagnol, A.C.; Huppert, F.A. Happy to Help? Exploring the Gactors Associated with Variations in Rates of Volunteering across Europe. Soc. Indic. Res. 2010, 97, 157-176. [CrossRef] 